March 2019

\title{
The Resurrection of Jesus Christ
}

Wyatt Sawyer

Follow this and additional works at: https://scholarworks.harding.edu/wyatt-sawyer-sermons

\section{Recommended Citation}

Sawyer, W. (2019). The Resurrection of Jesus Christ. Retrieved from https://scholarworks.harding.edu/ wyatt-sawyer-sermons/12

This Sermon is brought to you for free and open access by the Wyatt Sawyer Archive at Scholar Works at Harding. It has been accepted for inclusion in Wyatt Sawyer Sermon Outlines by an authorized administrator of Scholar Works at Harding. For more information, please contact scholarworks@harding.edu.

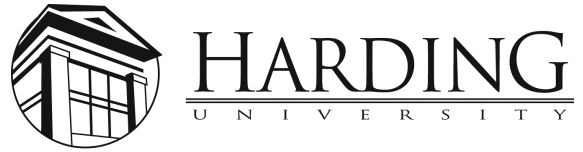




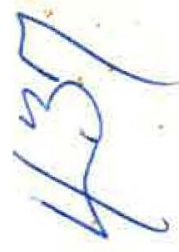

INT.

THE RESURRECTION OF JESUS CHRIST - - I COr. 15:9-26 *

PAUL in this reading clearly affirm 12 things Deals with all their

1. He was made an Apostle to cerve a crucifled, burled, BUT RISEN Lord Josue Christ. 2. All genuine Chrietians, along with Paul, believed if a
rearrected Savior.

3. Some Corinthians were denying the resurrection of Chriet Irom the dead. Irow the dend

4. A point of Ulogie: Ir there 1s No rosurecetion from the dead for anyone; then Chriet could not be alive- He io et111 dead. The Jor succeeded in etopping His work.

5. Preaching of the Apoetles and carly Chrietians is FipFr ralsed hollow, vain and uselese. A fantesy and a fraud?

6. The FAITH of all Christian wa fut1le and valuelese..... If Chrlst was not ralsed from the dead.

7. This would make the preachers and teachers of the RESURRECTION 11arq. F.t8g teachers and decelvers of the worat order.

8. All prior einnere were yet in their einseo-just thright. they had boen forgiven. Decelved and mislead.

9. Alloof the Bellevers, who were now dead, were loet, not saved as they had belleved, II Chriet was not ralsod from the dead.

10. If there is no resurrection-ethen these Chrietians were the most MISERABLE CREATURES of earth. Had based their hope on a meaninglese fabis:( If Christ were not risen.)

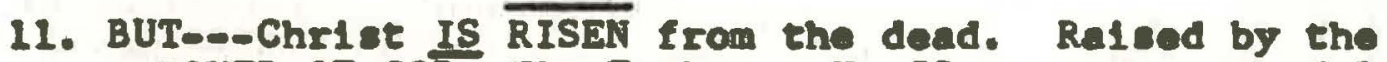
POHER OF GOD, HIs Father. He IS a resurrected Lord.

12. CONCLUSION: The Chrietian THEN and NOW 1s the happlest person fallvet

Has sreatnent enfort poesible.

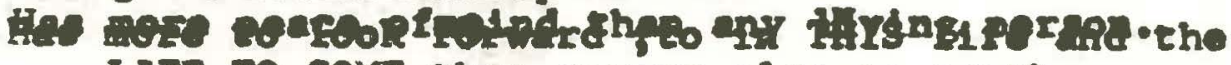

LIFE TO COME than anyone else on earth.

Enfoys the greatert ecurity over given to gan.

OBSERVATION: Everything a Chrietien IS, HAS BEDH or HOPES ITO BE hinges on the RESURRECTION OF JESUS CHRIST. 
1. IN SPITE OF THE GREAT WEIGHT OF INSURMOUNTABLE EVIDEMCE, THE RESURRECTION OF CHRIST HAS HOT CONEUUNCHALLENGED.

A. RENAN, Franch Infidel, in his book THI LIFE OF JESUS admite 8 vital facte about Jesue and His life on earth.

1. Jeous 11yed. Wes a real porson on earth as deseribed in N.T.

2. Jesus lived at the TIME the Now Testament cald Ho did.

3. Jeaus 11ved at the PLACE aseribad to Hin in the Bible.

4. He we GRUCIFIED by the Romans, at Inetigation of the Jew.

5. He wes Jifl? by a Jeatsh rich man, Joeeph of Arimethea.

6. The tomb was SEALED by the Roman Govt. Made vary sure.

7. The tomb was GUARDED by Roman guards-to provent tampering.

8. The body of Jesus was MISSIJG on the lat day of the weok.

BUT....B. RENAN, denied the CARDINAL DOCTRINE OF CHRISTIANITY That Jeaus we renwernated Irom the grave by the mor of God. Ho chellenged Romane 6:1-6.*

II. GHRISTIANS DO NOT FEAR IN THE LEAST TO ENTER INTO A DISCUSSION OF THE MERITS OF THE COSPEL OF CHRIST. HAe atood \& 211 vtand. Isa. 1:18. I These. 5:21. I Pet. 3:15.

A. ONE GRAND FACT REMAINS: Truth 18 truthl Faets are factel

1. If Chriet wre NOT ralsed Irom the dead, thon no emount of preaching, teeching, talking or portunding could makel1t so. If WHOLE WORLD belleved it SO, and it wyll not theppen -- it et1l1 would not be ool

2. If CHRIST yar: raised from the dead, then the WHOLE WORLD dinhlletins thateotil not keep it from being so.

III. SURVEY OF THE PROOFS FOR THE RESURRECTION WILL SETTLE THE MATTER FOR IANY FAIR-MINDED PERSON.

A. EVIDERCE OF THE "OPEN TOMB". Matt. 27:60. "grest stono" 1. Friends and encentes of Joure adnit tomb wa open \& enpty.

2. Quention: tho rolled arry that etones

a. Ronenel No. Sot the watch to keop it oeeupiod. b. Jewlich rularel No. Denanded the weteh to benl 1 t. c. Diselplesl No. Wanen had uplces ready to cabaim the body after the Sebbath days. Lk. $23: 56$. THEN WHO DID? BLble: Mett. 28:2. Angel \& enthquaic. 
B. EVIDENCE OF THE "EMPTY GRAVE". John 20:2. All agreed. 1. Question: Who renoved the body of Jesus from the tomb?

a. Roman guardal Why? To what juxpose? Charged to keopl b. Jewel If so, produce body and sottle the lesue. c. Apostleal Imposalble: John 20:9. Why holding apleen??

THEN WFO DID? Bible: Luke 24:1-8. Angels did $1 t$.

C. EVIDENCE OF THE "DISCARDED CLOTHES." All agreed there. 1. Question: Who folded the grave garments \& loft then neat?

a. Grave robbers: No. Take clothing with body. Cootly 1inen.

b. Apostles: No. Take the clothing with the body in haste.

c. Jews: No. Would produce body AND the elothes....settle.

THEN WHO DID? BIble: God did. Romane 6:3-4.

D. EVIDENCE OF "ABOVE 500 WITNESSES" I Cor. 15:1-8.

1. Question: Could over 500 witnesses be wrong?? Hardly.

a. Marys looked for gardner to help remove the tone. J.20:15.

b. Apostles refused to bellove the f1rst report. Mk. 16:11.

c. John, the Apost 10, did not understand the prophecy about the resurrection till he stew the the empty tomb and the folded grave garmente.

d. Can over 500 eye-wl tnesses be deceived by one who personally taught then for 40 days? Aete $1: 3$.

(1) If ware, then Requrrestlon was the greatent deception OF ALL TIMES.

(2) If were NOT, then the Renurrection is the grentest EVENT in ali human history.

INV: PURPOSE OF THE RECORDING OF THE RESURRECTION STORY: That you might BELIEVE in Jesus, as you belleve in no other.

That you will COME TO HIM as you Jwould 80 to to other. Totally, fully in complete eurrender of life \& soul.

JOHN EXPRESSED IT THIS WAY IN JOhn 20:30-31.

JESUS invites you to come to Him for the remiseion of joux sine.

He invites iyou to cone to Him for a hope for the future.

Ho invites you to conefto HIm for the peses of mind you crave in your coul. 